\title{
The Influence of Teacher Competencies on Student Motivation to Study Accounting at Secondary Vocational Schools in the Czech Republic
}

\author{
Ivana Kuchařová1, Kateřina Berková2, ${ }^{2, *}$, Daniela Pfeife rová1, Pavel Krpále k ${ }^{4}$ \\ ${ }^{1}$ Faculty of Economics and Management, Czech University of Life Sciences Prague, Czech Republic \\ ${ }^{2}$ Faculty of Finance and Accounting, University of Economics, Czech Republic \\ ${ }^{3}$ Department of Economic Studies, College of Polytechnics Jihlava, Czech Republic \\ ${ }^{4}$ College of International and Public Relations Prague, Czech Republic
}

Received September 27, 2019; Revised November 22, 2019; Accepted November 26, 2019

Copyright $\subseteq 2019$ by authors, all rights reserved. Authors agree that this article remains permanently open access under the terms of the Creative Commons Attribution License 4.0 International License

\begin{abstract}
The article is focused on the importance of selected pedagogical factors, which influence the motivation of Czech vocational secondary school students to study accounting. It examines teacher's and student's motivation for various fields of study and levels of education. Determining the key factors influencing motivation is fundamental to gradually improving the learning process. For the purposes of the research, the criteria selected were teacher's communication and presentation skills, teacher's ability to explain the curriculum, teacher's ability to develop thinking in students and teacher expertise. Some 187 students participated in the research that involved completing a questionnaire survey. The data were analyzed using the Kruskal-Wallis test and the modified Tukey method for multiple comparisons at a significance level of $5 \%$. The results are surprising. Pedagogical competencies do not influence student motivation to study accounting compared to other research studies. The different results can be primarily attributed to the structure of the research sample and to the more varied types of secondary vocational schools represented in the study. It will be necessary to carry out further research, expand the sample and examine other factors that may influence motivation, such as intellectual level, academic success, individual ambition, etc.
\end{abstract}

Keywords Student Motivation, Subject of Accounting, Teacher Competencies, Secondary Education

\section{Introduction}

Motivation comes from the Latin term pro moveo, which represents forward movement, and is the basic dynamic driving force of processes stemming from within a person. Motive, as the basic component of motivation, represents an incentive, the result of which some human activity begins, or, by contrast, some other activity is suspended or reduced. According to Ames [1], motivation is a mutually interacting relationship whereby motivated students need motivated teachers. In the educational process, motivation should encourage beneficial activities and limit undesirable ones. External and internal motives affect the activity of each individual. A combination of the two is optimal, working in tandem to achieve the desired outcome [2]. Motivation is one of the most important aspects in education [3] and cultivating a positive relationship between teacher and student is essential for the development of motivation [4]. However, as Nugent [5] states, other classroom interaction can also have a significant impact on motivation and that can go beyond the teacher's influence on students. The teacher's immediate behaviour and establishing an atmosphere of classroom democracy among students is considered to have a significant positive impact on the learning process in the classroom [6].

Motivation begins to form at the very beginning of compuls ory schooling, becoming an integral part of study and significantly impacting student performance. It is thus an area of interest for researchers, with authors focusing on research on pupil behaviour from primary school [7-10] through secondary school [11,12] to university [13-15]. During the transition from primary to secondary school, the motivation to study among adolescents tends to decrease, which, according to Krejčová [16], can be attributed to the fact that they have achieved their immediate goal of gaining entry to secondary school. Student motivation to study can 
increase again shortly before their school-leaving examinations.

The teacher is indeed probably most likely to incite students to learn in terms of the way in which external motivation affects the learning process. Several research studies have demonstrated that teachers to a large extent influence student outcome. However, pupils cannot merely be passive recipients of teacher activity. It is essential that teachers affirm students in their belief that their passion for learning is meaningful [17]. Although teachers cannot themselves create student motivation, a variety of factors in the classroom can influence motivation, such as the teacher student relationship, teacher behaviour in class, clas sroom atmosphere, and communication with the students [18-20]. Similarly, the type of subject taught has a significant effect on pupil motivation and on the creation of a pupil teacher relationship, as demonstrated by Hanandeh, Abdulah and Harun [3] in the case of the teaching of English. This was also shown in research conducted on students of German [21], which found that selecting the right activities (games) and educational assignments substantially stimulates the bond with the teacher. Keller, Neumann and Fischer [22] report that there has been a decline in recent years in secondary school students' interest in science subjects, specifically, for example, in physics. This was supported by further research [23] which found that pupils only study physics because of societal demands and not because they are interested in the area. In an analysis of the factors, which influence secondary school student attitudes to chemistry, authors of the study came to an interesting conclusion, finding that chemistry was among the more unpopular subjects [24]. Even in cases where teachers required and supervised regular, systematic preparation by students during their studies, statistically there was no significant impact on the students' final examination results in accounting subjects. What did, however, have an impact on student success or failure in exams were other factors such as personal motivation, teaching methods and teacher expertise [25]. Stejskalová, Komárková, Bednářová and Strach [15] found that it is advisable to include active learning in accounting teaching methods in the form of practical case studies from real corporate life. In their research, they evaluated student willingness to adopt this new method and found that men are better at adopting new teaching methods than women.

On the other hand, according to Mareš [26], it is very easy to demotivate and hinder pupils in their efforts to glean new information, with a substantial decrease in student curiosity when teachers are indifferent and lax. However, the research found that when it comes to student academic self-efficacy, if the teacher is good, student competencies and self-confidence increase. Teacher expertise in the subject has been identified as a determining factor in terms of student outcomes, while teacher motivation is seen as a decisive factor affecting student interest in the subject. The research, which examined the current impact of both factors, demonstrated the importance of taking both teacher expertise and motivation into account to improve students' cognitive and affective outcomes [27]. In their research, Brophy [28], Nye and Hedges [29] and Peterson, Marx and Clark [30] also found that teachers play an important role in influencing student outcomes.

The aim of the article is to establish the importance of selected factors in terms of their influence on the motivation of second-and third-year students of accounting at secondary vocational schools. The analys is is based on empirical research carried out in 2018. The subject of the study is teacher pedagogical competencies and the way in which they influence student motivation to study accounting. For research purposes, teacher communication and presentation skills, teacher ability to explain the curriculum, teacher ability to develop thinking among students and teacher expertise were selected.

Arising from the above objective are the following research hypotheses, which are subject to verification:

1. The teacher competencies examined in the study influence the motivation of second-year students in the subject of accounting.

2. The teacher competencies examined in the study influence the motivation of third-year students in the subject of accounting.

\section{Materials and Methods}

The empirical study is based on quantitative research. The findings can be used to draw general conclusions in given conditions and at the level of the research subjects. Research hypotheses are set for verification purposes. The study was conducted between October and December 2018 at Czech secondary vocational schools.

The 2018 data is analysed by year group, and the paper also looks at the development of teacher motivation through a comparison of the findings for 2015 [11]. In 2015 the authors examined the influence of teacher competencies on the motivation of business academy students to study accounting in the Czech Republic. This study demonstrated that teachers at the business academies that were included in the study were able to motivate students in the subject of accounting, primarily by explaining the curriculum. Some 277 second-and third-year students participated in this research study. Therefore, these were students who had already completed first- and second-year studies in accounting. In the Czech Republic, the subject of accounting is usually incorporated into the curriculum of business academies for three years. Therefore, we were interested in the current situation in secondary vocational schools, which offer accounting both as a subject for the final school-leaving exam (maturita) and as a non-maturita subject.

The methodological research is not only based on an empirical study conducted in the Czech Republic [11]; it is 
also inspired by other research studies of a similar nature in international publications $[9,15]$.

\subsection{Res earch Sample}

Research in 2018 was conducted in all 14 regions in the Czech Republic. The results are relevant with the predictive value, as they show the given situation in the Czech Republic.

Some 102 business academies were addressed, all of which were characterized by the fact that the subject of accounting is a maturita/school-leaving examination. An additional 45 secondary vocational schools were also addressed which specialise in areas other than economics, but where the subject of accounting is also taught. These schools are registered with the Czech Ministry of Education, Youth and Sports. A total of 187 secondary schoolstudents participated in the study, of which 80 were from business academies, where economics subjects are part of the final school-leaving exam (maturita) and 107 are students from other vocational secondary schools, where economics subjects merely complement other vocational education in areas such as electrical engineering, engineering, the hotel industry, tourism, management, etc.

Considering the objective of this research study and the hypothesis being verified, the research sample is structured by year group across all participating secondary schools (Table 1).

Table 1. Structure of research sample

\begin{tabular}{|c|c|c|}
\hline Year & Absolute frequency & $\begin{array}{c}\text { Relative } \\
\text { frequency }(\%)\end{array}$ \\
\hline 2ndyear & 77 & 41.2 \\
\hline 3rdyear & 110 & 58.8 \\
\hline Total & 187 & 100.0 \\
\hline
\end{tabular}

\subsection{Instrument and Procedures}

A questionnaire survey was the method used for data collection. This method was used initially to identify the characteristics of respondents (primarily the secondary schoolat which they study and their year group). Given that the analysis is not focused on gender differences, this characteristic of the respondents is not examined in further detail. Furthermore, student attitudes to the teacher's motivational influence in the subject of accounting were ascertained, i.e., to what extent teacher competencies motivates the student to study accounting. Respondents evaluated the extent to which they were motivated on a scale of 1-5, with a score of 1 indicating the lowest level of motivation for a given ability and 5 the highest. This evaluation was conducted using a scale of 1-5 points.

Based on an analytical approach, students rated teachers for the five abilities monitored in the study, each containing a different number of aspects describing a teacher's ability (known as files) in the given category. These abilities (categories) contain a total of 16 files that describe each category as accurately as possible (Table 2).

Table 2. Description of categories and files of examined abilities

\begin{tabular}{|c|c|l|}
\hline Category & $\begin{array}{c}\text { Number of } \\
\text { Abilities in } \\
\text { Category }\end{array}$ & \multicolumn{1}{|c|}{ Abilities in Category } \\
\hline $\begin{array}{c}\text { Communication } \\
\text { Skills }\end{array}$ & 6 & $\begin{array}{l}\text { Pronunciation, interest, pace } \\
\text { and melody, keeping } \\
\text { focused, paying attention, } \\
\text { listening }\end{array}$ \\
\hline $\begin{array}{c}\text { Presentation } \\
\text { Skills }\end{array}$ & 4 & $\begin{array}{l}\text { Examples of real-life } \\
\text { situations, good actor, } \\
\text { maintaining eye contact, } \\
\text { dealing with stage fright }\end{array}$ \\
\hline $\begin{array}{c}\text { Explaining the } \\
\text { Subject Matter }\end{array}$ & 3 & $\begin{array}{l}\text { Practical meaning of the } \\
\text { curriculum, adopting } \\
\text { unconventional ideas, } \\
\text { explaining mistakes }\end{array}$ \\
\hline $\begin{array}{c}\text { Ability to } \\
\text { Develop Thinking }\end{array}$ & 2 & $\begin{array}{l}\text { Interest in developing a task, } \\
\text { leading to thinking }\end{array}$ \\
\hline Expertise & 1 & $\begin{array}{l}\text { Answering factually correct } \\
\text { and consistently to all } \\
\text { questions }\end{array}$ \\
\hline
\end{tabular}

\subsection{Data Analysis}

In order to verify null hypotheses, the non-parametric Kruskal-Wallis test was used since the data does not have a normal distribution. The one-way ANOVA method was used to ascertain the differences between the teachers' observed abilities in relation to the motivational effect on the students. This method compares the mean values of multiple selections. To find out which of the selections (teacher abilities monitored) have significant differences, a pair comparison test (a modification of Tukey's multiple comparison method) - the Tukey-Kramer method - was used because of the unbalanced range of files within these selections, i.e. each selection contains a different number of files (Table 2).

Verification of the null hypothesis using the above statisticaltests was performed at a significance level of $5 \%$. The data was analysed with the support of NCSS statistical software. For the purpose of comparing student attitudes to the teacher abilities monitored in the study in terms of the level of motivational effect, these aspects are evaluated as the average of the points assigned by students to individual teacher requirements in respect of the relevant statement. Zero hypotheses were formulated as follows:

- $\mathrm{H}_{0-1}$ : The teacher skills examined do not have an impact on the motivation of second-year students of accounting.

- $\mathrm{H}_{0-2}$ : The teacher skills examined do not have an impact on the motivation of third-year students of accounting.

\section{Results}

Null hypotheses regarding the influence of the examined factors on the motivation of second and third-year students at secondary vocational schools were first verified using the 
Kruskal-Wallis test, at a significance level of 5\% (Table 3).

Table 3. Kruskal-Wallis test

\begin{tabular}{|c|c|c|c|}
\hline df & Chi-Square & $\mathbf{p}$ & $\begin{array}{c}\text { Decision } \\
(\mathbf{p}<\mathbf{0 . 0 5})\end{array}$ \\
\hline 4 & .8088 & .9373 & Accept $\mathrm{H}_{0-1}$ \\
\hline 4 & 2.3186 & .6774 & Accept $\mathrm{H}_{0-2}$ \\
\hline
\end{tabular}

Data analysis shows that at a 5\% significance level we do not reject both null hypotheses $\mathrm{H}_{0-1}$ and $\mathrm{H}_{0-2}$. This means that teacher pedagogical skills do not have an impact on student motivation in accounting.

The situation is illustrated in Table 4, which demonstrates the differences between the teacher abilities examined using the mean value by means of multiple comparisons - the Tukey-Kramer method at a 5\% significance level. The results are shown for second-year students at vocational secondary schools.

Table 4. Tukey-Kramer test - differences bet ween competencies/skills - second-year students

\begin{tabular}{|c|c|c|}
\hline Competency/skills & Average & $\begin{array}{c}\text { Differences } \\
\text { between } \\
\text { competencies }\end{array}$ \\
\hline $\begin{array}{c}\text { Communication } \\
\text { Skills }\end{array}$ & 2.623 & None \\
\hline Presentation Skills & 2.636 & None \\
\hline $\begin{array}{c}\text { Explaining the } \\
\text { Subject Matter }\end{array}$ & 2.763 & None \\
\hline $\begin{array}{c}\text { Ability to Develop } \\
\text { Thinking }\end{array}$ & 2.682 & None \\
\hline Expertise & 2.740 & None \\
\hline
\end{tabular}

The mean values demonstrate that there are no differences between pedagogical competencies in terms of motivating second-year students to study accounting. Students evaluations of competencies are balanced. However, the ability to explain the subject matter have the highest evaluation, due to the nature of the subject being taught.

The differences between competencies are shown in the box diagram using exploratory analysis (Figure 1).

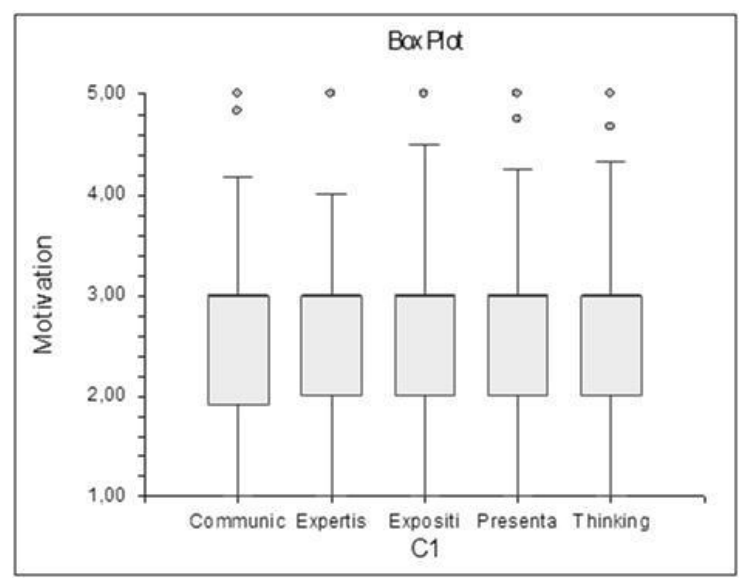

Figure 1. Exploratory analysis of differences - second-year students
The situation is again illustrated in Table 5, which illustrates the differences between the teacher abilities examined using the mean value by means of multiple comparisons - the Tukey-Kramer method at a 5\% significance level. The results are shown for third-year students at vocational secondary schools.

Table 5. Tukey-Kramer test - third-year students

\begin{tabular}{|c|c|c|}
\hline Competency/skills & Average & $\begin{array}{c}\text { Differences } \\
\text { between } \\
\text { competencies }\end{array}$ \\
\hline $\begin{array}{c}\text { Communication } \\
\text { Skills }\end{array}$ & 3.185 & None \\
\hline Presentation Skills & 3.243 & None \\
\hline $\begin{array}{c}\text { Explaining the } \\
\text { Subject Matter }\end{array}$ & 3.268 & None \\
\hline $\begin{array}{c}\text { Ability to Develop } \\
\text { Thinking }\end{array}$ & 3.273 & None \\
\hline Expertise & 3.373 & None \\
\hline
\end{tabular}

Mean values show that there are no differences between pedagogical competencies in motivating third-year students to study accounting. Student evaluation is balanced. However, teacher expertise is evaluated highest which, in comparison with other competencies, motivates students most. However, no significant differences were found for the different competencies in terms of student motivation.

The differences between competencies are shown in the box diagram using exploratory analys is (Figure 2).

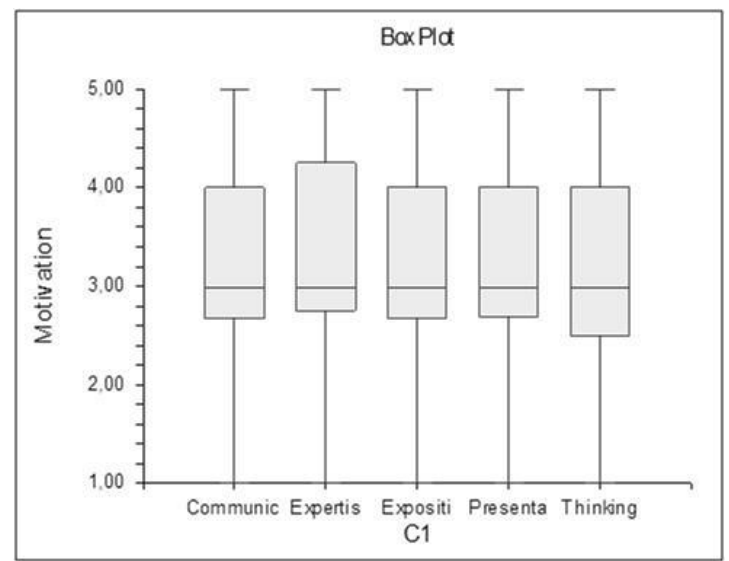

Figure 2. Exploratory analysis of differences - third-year Students

In a comparison of the two year groups at all the vocational secondary schools that participated in the 2018 study, it can be concluded that motivation is higher among third-year students.

Teacher requirements also change depending on the year group, and teachers should be able to better motivate students in the subject.

\section{Discussion}

According to the results of the test, neither of the two 
hypotheses on the impact of teacher competencies in the motivation of students of accounting was confirmed. Therefore, the test evaluation shows that the teacher competencies examined do not have an impact on student motivation to study accounting for second-and third-year students at vocational secondary schools.

When compared with the findings of research conducted at business academies in the Czech Republic in 2015 [11], the results were completely different, with the 2015 study demonstrating that student motivation to study accounting is influenced by teacher competencies. The greatest influence was observed for teacher expertise, followed by the ability to explain the subject matter. So how is it possible that the research findings were completely different three years later? This change may be because the composition of the students interviewed (respondents) was significantly different. In 2015 students from only three business academies participated in the research, where the subject of accounting was part of the school-leaving examination/maturita (written and oral). This creates an awareness among students of the complexity of the subject and the exams, giving them the internal motivation to fulfil the conditions of study, i.e. they want to pass the schoolleaving examination. At the same time, it can be assumed that the students of these three business academies would have a greater interest in accounting, also in terms of being able to use the subject in the future. This attitude leads to students actively targeting teachers and accepting their influence by allowing themselves to be motivated by the teacher's approach. In order to develop internal motivation, we need to provide students with information that will motivate them. The teacher, through his/her pedagogical competencies, is responsible for ensuring that this is the case. There is a two-way relationship between internal motivation and cognitive processes. Without internal motivation, cognitive processes cannot be effectively developed. However, internal motivation is created and increased through cognition [31]. Another factor that may affect the results of the research study conducted in the case of secondary schoolstudents is the degree to which they are able to reliably assess teacher competencies [32].

In 2018 only $42 \%$ of the student sample examined were students from business academies, with $58 \%$ from other vocational secondary schools with other core subjects, where accounting was a non-school-leaving exam subject, with students studying a different area of expertise such as engineering, electrical engineering, tourism, the hotel industry, etc. Given the relatively significant number of secondary schools with a vocational specialization, student motivation in this area is clearly weaker. Accounting teachers do not have to make such an effort to make the topic attractive to pupils because they will not be using accounting in practice. As a result, the given subject loses its motivational potential for pupils. In the case of secondary school students, their level of success in school does not affect their position in future professional life [33]. Some students only decide to go to secondary school to get their secondary school-leaving exam certificate (maturita), which is an essential requirement in today's world to get an average position on the job market. However, no future employer is going to examine the student's results in the individual subjects, and thus many students are content with below-average learning outcomes. In the case of more ambitious students who wish to continue to study at university, the motivation to achieve better results may also be lacking, as many universities accept students without them having to sit entrance exams to test their level of knowledge. However, another important factor that affects motivation to study accounting is the intellectual level of the individual. This was proven in research conducted by Berková, Krejčová, Králová, Krpálek, Krpálková and Kolářová [12] in the context of business academies. However, our research study did not take this factor into account. It can therefore be perceived as an incentive for further research in secondary vocational schools.

Research published by Frenzel, Taxer, Schwab and Kuhbandner [34] demonstrates that the teacher's displayed enthusiasm and perception of the students' emotional experiences during lessons sends positive emotional signals to students, resulting in significant interaction effects on perceived motivation and on subjective (individual) learning. The same conclusion was reached by Keller, Hoy, Goetz and Frenzel [27] who argue that teacher enthusiasmhas a positive impact on the quality of teaching and learning. Teacher enthusiasm is reflected in teaching, for instance, in the different ways of expression (speech speed, intonation, choice of specialized vocabulary) and in behaviors such as gestures, attitudes, facial expression, body language [35], which can both individually and collectively connect with the student and arouse his/her interest in the given subject [36]. The teaching method can also be influenced by the teacher's personal motivation. Recepoğlu [37] states that a teacher's age and teaching experience are significant variables affecting work motivation. Regardless of gender, teachers aged 22-30 and 51 and over were the most motivated teachers. A deeprooted social assumption is the notion that teachers are supposed to inspire positive emotions and arouse student interest in a particular subject - preferably in every subject in cases where the student wishes to identify with the teacher and be "as good as him/her". Induced interest can be considered as a specific type of internal motivation, is related to specific activities, and promotes long-term performance in the study of certain subjects, e.g. a form of combined studies [38]. Banfield's research [39] found that there are no statistically significant differences in learning motivation that can be attributed to the type of teacher and teacher behavior, ranging from appropriate to inappropriate. By contrast, the lecturer has an important role in increasing student interest [40].

\section{Conclusions}

The research conducted in 2018 at secondary vocational 
schools in the Czech Republic did not prove that teacher pedagogical competencies influence student motivation to study accounting. These findings can mainly be attributed to the difference in the structure of the research sample in 2018 to that in 2015, when the first research study of this kind was conducted [11]. In 2018, the sample comprised not only students from business academies, but also from other vocational secondary schools with different areas of specialisation, where accounting is not classified as a school-leaving examination subject (maturita subject). We consider this factor crucial in terms of impact on the research results. To sum up, motivation can be influenced by a subject's status on the school curriculum. By this, we mean whether the subject is a maturita subject or merely an obligatory or optional subject. If the subject is a maturita subject, then students are motivated both by their interest in passing the final exam (maturita) and by the different approach taken by the teacher. The personality of the teacher varies considerably depending on the objective and on student requirements depending on the profile of the graduate. However, a teacher's goal is not only to educate students and prepare them for their future profession or for further studies at university, but to motivate them. This goal should be met in different types of secondary schools and in all subjects.

Therefore, this research study can be considered an inspiration for further research both at the national level and especially at the international level. We consider it prudent to compare educational systems internationally and thus pinpoint key factors that influence student motivation to study accounting or related economics subjects. These new findings can then be passed on to teachers and put into practice, thereby improving the current situation. Therefore, the research will be extended to focus more on the way in which teacher personality influences student motivation at various types of secondary schools which specialise in economic education and on finding out the extent to which student success in economic subjects correlates with their own internal motivation or with the motivation of teachers to carry out their profession.

\section{Acknowledgements}

This research was supported by the Project No. IGS VŠE F1/7/2018 and the Project VŠE No. IP 100040.

\section{REFERENCES}

[1] C. A. Ames. Motivation: what teachers need to know, Teachers College Record: University Of Illinois At UrbanaChampaign, Vol. 91, No. 3, 409-421, 1990.

[2] M. Slavík. Vysokoškolská pedagogika: pro odborné vzdělávání, Grada Publishing, Praha, 2012.
[3] A. Hanandeh, Z. Abdullah, J. Harun. The Effects of A Serious Game Activity and Learning Tasks on Students' Motivation Towards Reading Skill, International conference on engineering education, New York, 214-219, 2018.

[4] T. Whitaker. What great teachers do differently: seventeen things that matter most. Larchmont, NY: Eye on Education, 2012.

[5] T. T. Nugent. The Impact of Teacher-Student Interaction on Student Motivation and Achievement, Disertation, University of Central Florida Orlando, 2009.

[6] J. C. Kwitonda. Foundational aspects of classroom relations: associations between teachers' immediacy behaviours, classroom democracy, class identification and learning, Learning Environ Res, Vol. 20, No. 3, 383-401, 2017.

[7] S. C. Broussard, M. E. B. Garrison. The Relationship Between Classroom Motivation and Academic Achievement in Elementary-School-Aged Children, Family and Consumer Sciences Research Journal, Vol. 33, No. 2, 106-120, 2004.

[8] U. Schiefele, E. Schaffner. Teacher interests, mastery goals, and self-efficacy as predictors of instructional practices and student motivation, Contemporary Educational Psy chology, Vol. 42, 159-171, 2015.

[9] U. Schiefele. Classroom management and mastery-oriented instruction as mediators of the effects of teacher motivation on student motivation, Teaching and Teacher Education, Vol. 64, 115-126, 2017.

[10] C. C. Tsai. Relationships between student scientific epistemological beliefs and perceptions of constructivist learning environments, Educational Research, Vol. 42, No. 2, 193-205, 2000.

[11] K. Berková, K. Krejčová. Effect of teachers' abilities on students' motivation with varying levels of intellectual abilities in the economics, Journal on Efficiency and Responsibility in Education and Science, Vol. 9, No. 3, 81$87,2016$.

[12] K. Berková, K. Krejčová, A. Králová, P. Krpálek, K. Krelová Krpálková, D. Koláŕová. The conceptual four-sector model of development of the cognitive process dimensions in abstract visual thinking, Problems of Education in the 21st Century, Vol. 76, No. 2, 121-139, 2018.

[13] R. Breen, R. Lindsay. Academic research and student motivation, Studies in Higher Education, Vol. 24, No. 1, 75-93, 1999.

[14] K. Berková, J. Borůvková, L. Lízalová. Motivation of Students of Economic and Technical Fields as a Tool of Competitiveness of Universities and Colleges: Empirical Study, Journal on Efficiency and Responsibility in Education and Science, Vol. 11, No. 4, 72-77, 2018.

[15] I. Stejskalová, L. Komárková, M. Bednářová, P. Štrach. Student Adoption of a Non-Traditional Teaching Method in Accounting: How Previous Experience Impedes Willingness to Change, Journal on Efficiency and Responsibility in Education and Science, Vol. 12, No. 1, 1$11,2019$.

[16] L. Krejčová. Psychologické aspekty vzdělávání 
dospívajících, Grada Publishing, Praha, 2011.

[17] D. Dvořák. Efektivní učení ve škole, Portál, Praha, 2005.

[18] M. Allen, P. L. Witt, L. R. Wheeless. The Role of Teacher Immediacy as a Motivational Factor in Student Learning: Using Meta-Analysis to Test a Causal Model, Communication Education, Vol. 55, No. 1, 21-31, 2006.

[19] J. Kerssen-Griep. Teacher communication activities relevant to student motivation: Classroom facework and instructional communication competence, Communication Education, Vol. 50, No. 3, 256-273, 2001.

[20] J. J. Velez, J. Cano. The Relationship between Teacher Immediacy and Student Motivation, Journal of Agricultural Education, Vol. 49, No. 3, 76-86, 2008.

[21] M. Lachout. University students' motivation to study the German language, Acc Journal, Vol. 24, No. 3, 89-95, 2018.

[22] M. M. Keller, K. Neumann, H. E. Fischer. The impact of physics teachers' pedagogical content knowledge and motivation on students' achievement and interest, Journal of Research in Science Teaching, Vol. 54, No. 5, 586-614, 2017.

[23] M. Kekule, V. Žák. Postoje žáků k výuce fyziky v České republice - vy brané vý sledky, Scientia in educatione, Vol. 1, No. 1, 51-71, 2010.

[24] K. Švandová, M. Kubiatko. Faktory ovlivňující postoje studentů gymnázií $\mathrm{k}$ vyučovacímu předmětu chemie, Scientia in educatione, Vol. 3, No. 2, 65-78, 2012.

[25] I. Kuchařová, D. Pfeiferová, M. Prášilová. Results analysis of the exam in accounting theory, International Conference on Efficiency and Responsibility in Education in Prague, 96-104, 2018.

[26] J. Mareš. Nevhodné chování učitelů k žákům a studentům, Studia paedagogica, Vol. 18, No. 1, 1-36, 2013.

[27] M. M. Keller, A. W. Hoy, T. Goetz, A. C. Frenzel. Teacher Enthusiasm: Reviewing and Redefining a Complex Construct, Educational Psychology Review, Vol. 28, No.4, 743-769, 2016

[28] J. E. Brophy. Teacher behavior and its effects, Journal of Educational Psychology, Vol. 71, No. 6, 733-750, 1979.

[29] B. Nye, S. Konstantopoulos, L. V. Hedges. How Large Are Teacher Effects? Educational Evaluation and Policy Analy sis, Vol. 26, No. 3, 237-257, 2004.

[30] P. L. Peterson, R. W. Marx, C. M. Clark. Teacher Planning, Teacher Behavior, and Student Achievement, American Educational Research Journal, Vol. 15, No. 3, 417-432, 1978.

[31] A. Broks. Systems theory of systems thinking: general and particular within modern science and technology education, Journal of Baltic Science Education, Vol. 15, No. 4, 1-3, 2016.

[32] U. I. Ogbonnaya. The reliability of students' evaluation of teaching at secondary school level, Problems of Education in the 21st Century, Vol. 77, No. 1, 97-109, 2019.

[33] M. Vágnerová. Vývojová psychologie: dětství, dospělost, stáŕí. Portál, Praha, 2000.
[34] A. C. Frenzel, J. L. Taxer, C. Schwab, C. Kuhbandner. Independent and joint effects of teacher enthusiasm and motivation on student motivation and experiences: A field experiment, Motivation and Emotion, Vol. 43, No. 2, 255$265,2019$.

[35] I. Burić. The role of emotional labor in explaining teachers' enthusiasm and students' outcomes: A multilevel mediational analysis, Learning and Individual Differences, Vol. 70, 12-20, 2019.

[36] ] J. L. Taxer, A. C. Frenzel. Facets of teachers' emotional lives: A quantitative investigation of teachers' genuine, faked, and hidden emotions, Teaching and Teacher Education, Vol. 49, 78-88, 2015.

[37] E. Recepoğlu, E. Investigating motivation of primary and secondary school teachers in terms of demografic variables according to teacher opinions: A case of Turkey, Problems of Education in the 21st Century, Vol. 51, 104-112, 2013.

[38] U. Schiefele. Interest, learning, and motivation, Educational Psy chologist, Vol. 26, No. 3-4, 299-323, 1991.

[39] S. R. Banfield. How do college/university teacher misbehaviors influence student cognitive learning, academic self-efficacy, motivation, and curiosity? Disertation, West Virginia University), 2009. Online available from https://researchrepository.wvu.edu/cgi/view content . cgi article $=4518 \&$ context $=$ etd.

[40] P. Sukandi, M. H. M. Saudi, O. Sinaga. The Influence on the style of teaching in entrepreneurship courses: A study on lecturer against students' interest in entrepreneurship, Universal Journal of Educational Research, Vol. 7, No. 4A, 60-66, 2019 